\title{
Identification of drugs as regulators on the activity of Egr-1 promoter in human fibroblasts transduced with Ad $\Delta$ egr-1-Luc7
}

\author{
Identificación de fármacos reguladores de la actividad del promotor Egr-1 en fibroblastos \\ humanos transducidos con Adsegr-1-Luc7
}

\begin{abstract}
Francisco Martínez-Flores ${ }^{1-3 *}$, Hugo Sandoval', Elizabeth Arce de la Vega ${ }^{1}$, Ricardo J. García-Cavazos², Fausto A. Jiménez-Orozco 3 , Margarita Valdes-Flores ${ }^{4}$ and Juan A. Madinaveitia-Villanueva ${ }^{4}$

${ }^{1}$ Molecular Biotherapeutics Program, Skin and Tissue Bank, Instituto Nacional de Rehabilitación Luis Guillermo Ibarra Ibarra, Secretaría de Salud; ${ }^{2}$ Department of Genetics, Hospital General de México, Secretaría de Salud; ${ }^{3}$ Pharmacology Department, Faculty of Medicine, Universidad Nacional Autónoma de México; ${ }^{4}$ Instituto Nacional de Rehabilitación Luis Guillermo Ibarra Ibarra, Secretaría de Salud. Mexico City, Mexico
\end{abstract}

\begin{abstract}
Introduction: The early growth response protein (EGR-1) is a transcription factor involved in cell differentiation and proliferation, whose expression is regulated by its promoter in response to various physical, chemical and drug factors. Hereby, we describe some of the main effects of steroid drugs and EGF-1 on promoter activity, through a reporter system transduced by Adsegr-1Luc7 in human primary fibroblasts (HPF). Methods: Human primary fibroblasts transduced with AdDegr-1-Luc7 were exposed to betamethasone, hydrocortisone, dexamethasone, testosterone, beta-estradiol, and EGF-1 during 1, 3 and $6 \mathrm{~h}$. Reporter assay was quantified by luminometry. Results: The activity of the promoter in presence of betamethasone, hydrocortisone, dexamethasone, testosterone and beta-estradiol were similar to the basal activity of the promoter at 1, 3 and $6 \mathrm{~h}$. The positive control showed an activity 17.8 folds higher $(p \leq 0.05)$ at 6 h. EGF-1 showed activity of 22.07 folds greater than cells without drug. Conclusion: The activity of the EGR-1 promoter in human fibroblasts is negatively regulated by steroid drugs and positively by the EGF-1.
\end{abstract}

KEY WORDS: EGR-1 promoter. Steroids. Adenovirus. Human fibroblasts. EGF-1. Gene therapy.

\section{Resumen}

Introducción: La proteína de respuesta temprana a crecimiento 1 (EGR-1) es un factor de transcripción involucrado en la diferenciación y la proliferación celulares, cuya expresión es regulada por su promotor en respuesta a diversos factores físicos y químicos, y a fármacos. Aquí se describen algunos de los principales efectos de los fármacos esteroides y del factor de crecimiento epitelial 1 (EGF-1) sobre la actividad del promotor, mediante un sistema reportero transducido por el adenovirus Addegr-1-Luc7 en fibroblastos primarios humanos. Método: Los fibroblastos primarios humanos fueron cultivados en pase 5, transducidos con Adsegr-1-LuC7 y expuestos a betametasona, hidrocortisona, dexametasona, testosterona, beta-estradiol y EGF-1 durante 1, 3 y 6 horas. La actividad de reportero fue cuantificada por luminometría y ajustada a la concentración de proteínas totales. Resultados: La actividad del promotor en presencia de betametasona, hidrocortisona, dexametasona, testosterona y beta-estradiol fue similar a la actividad basal del promotor a las 1, 3 y 6 horas. El control positivo mostró una actividad 17.8 veces mayor a las 6 horas $(p \leq 0.05)$. De manera similar, las células expuestas a EGF1 mostraron una actividad 22.07 veces mayor que las células sin fármaco. Conclusión: La actividad del promotor Egr-1 en fibroblastos humanos es regulada negativamente por los fármacos esteroides y positivamente por el EGF-1.

PALABRAS CLAVE: Promotor Egr-1. Esteroides. Adenovirus. Fibroblastos humanos. EGF-1. Terapia génica.

\author{
Correspondence: \\ *Francisco Martínez Flores \\ Calzada México-Xochimilco 289 \\ Col. Arenal de Guadalupe \\ C.P. 14389, Ciudad de México, México \\ E-mail: fcomartinef@comunidad.unam.mx
}

Date of reception: 28-02-2018

Date of acceptance: 25-04-2018

DOI: $10.24875 / C I R U E . M 18000035$
Cir Cir. 2018;86:201-208

Contents available at PubMed www.cirugiaycirujanos.com 


\section{Introduction}

The early growth response protein (EGR-1) is a transcription factor involved in the activation of mitogenic pathways and cell differentiation in embryonic tissues, in the lung, joint tissue, skin fibroblasts and glioma and leukemia tumor cells ${ }^{1-5}$. EGR-1 expression is essentially regulated by the gene promoter region in response to different inducers, including factors such as temperature, osmotic and osmotic concentration changes, pressure, hypoxia, ultraviolet (UV) light, gamma radiation, and stimulation of tumor growth factor beta transcriptional activity and of proteins involved in the pathway of collagen synthesis ${ }^{6-10}$.

The specific mechanism for the regulation of transcriptional activity of the promoter is mediated by cyclic AMP-responsive binding sequences (CRE), serum response elements or through EGR1 protein binding sites (EBS) as a negative self-regulation mechanism and that are found in the first 600 base pairs upstream of the transcription start site (TATA box) ${ }^{11-15}$.

EGR-1 protein mitogenic effect is mediated by its folding into zinc fingers that recognize consensus sequences (CCGG/TGGGCCG) in the promoter of several genes and that, in addition, confers a self-regulation mechanism through the binding site on its own promoter (EBS) $)^{16,17}$.

Natural and synthetic glucocorticoids are molecules with pleiotropic activity, whose mechanism of action is mediated by cytoplasmic receptors that translocate the nucleus and activate glucocorticoid-responsive sequences ${ }^{18}$. Once in the nucleus, the drug-receptor complex binds to sequences (5'AGAACAN-NNTGTTCT-3') of promoters that regulate the activity of protein kinases or proteins involved in mitogenic signaling pathways (Fos, Jun and Egr-1), as well as of mitogen-activating kinases (MAP-kinases, ERK and ELK) ${ }^{19,20}$.

Steroid drugs represent one of the essential therapeutic elements to regulate systemic and local inflammatory processes. However, their effects on promoter activity are not fully known, as in the case of EGR-1 in skin fibroblasts ${ }^{21-23}$.

Herein, we report the effects of steroid-derived drugs (dexamethasone, hydrocortisone, betamethasone), steroid hormones such as beta-estradiol and testosterone, and epithelial growth factor 1 (EGF-1), with the purpose to identify pharmacological regulators (negative or positive) on the EGR-1 protein promoter.

\section{Method}

\section{Obtainment of primary human fibroblasts}

The experimental assays described in this article are derived from the research protocol with registration number INR-CII-14B-2011, authorized by Instituto Nacional de Rehabilitación Luis Guillermo Ibarra Ibarra Internal Research Committee. The primary human fibroblasts (PHF) were obtained from the Skin and Tissue Bank of the same Institute, in accordance with the standardized protocol (PR-DQ17- ISO-9001- 2008). Briefly, the PHFs were isolated from medium-thickness dermal allografts obtained from multi-organ donors and subjected to enzymatic cleavage with $1 \%$ collagenase in modified Dulbecco's phosphate buffered solution (D-PBS) for 1 hour. They were immediately centrifuged at $1000 \mathrm{G}$ for $10 \mathrm{~min}$ utes at $4{ }^{\circ} \mathrm{C}$ and washed with modified Dulbecco's minimum essential medium (D-MEM) supplemented with antibiotics and heat-inactivated fetal bovine serum (FBS) (Gibco-Invitrogen Corp.). Subsequently, the obtained cells were seeded in 10-cm diameter boxes in the presence of D-MEM medium supplemented with 10\% FBS and antifungal antibiotic at standardized concentrations (penicillin G, streptomycin and amphotericin B).

\section{Culture of primary human fibroblasts}

The PHF cells were cultured in D-MEM medium with $10 \%$ FBS and $5 \mathrm{mM}$ ascorbic acid in an environment with $5 \% \mathrm{CO}_{2}, 20 \% \mathrm{O}_{2}$ and $100 \%$ humidity at $37{ }^{\circ} \mathrm{C}$, until $80 \%$ confluence was reached in collagen-covered T-75 culture boxes (GrainerBioOne, Corp., Germany). The cells were disaggregated and reseeded until passage 5. Subsequently, they were cryopreserved in liquid nitrogen until the drug induction assays were performed.

\section{Drug-induction experimental model}

The system for evaluation and analysis of the pharmacological induction effect on the promoter is based on a reporter system, transduced by a third-generation non-replicating adenovirus ( $\operatorname{Ad} \Delta 3$ ). The cells were cultured and infected with a non-replicating recombinant adenovirus that transduces the Egr-1 promoter cassette, to direct the expression of the luciferase gene cloned in Ad-egr-1-Luc7 (Fig. 1). Luciferase is an enzyme expressed in lampyridae (Insecta-Coleoptera) that hydrolyzes luciferin in the presence of ATP and 


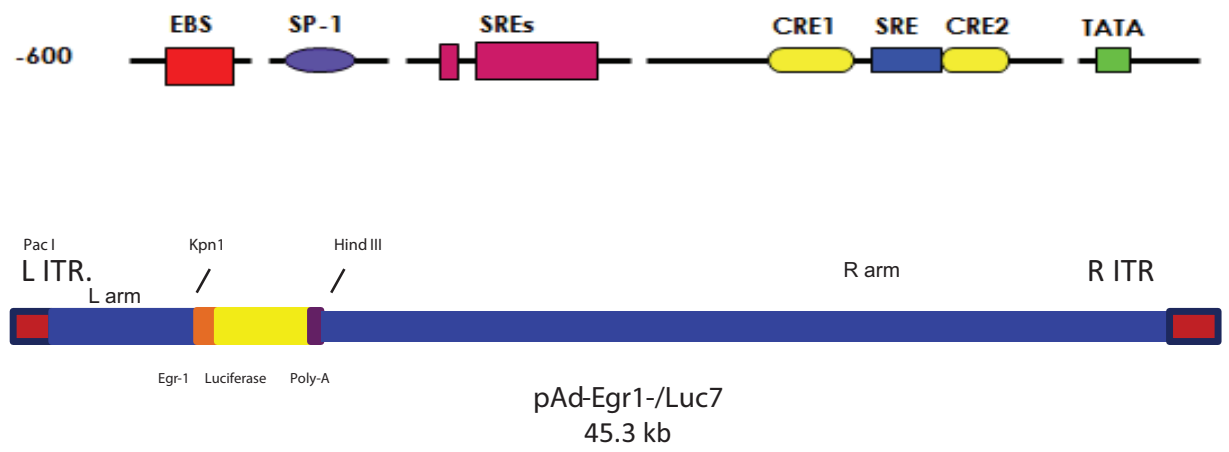

Figure 1. Structure of the Ad-Egr-1-Luc7 non-replicating recombinant adenovirus. Diagram illustrating reporter cassette incorporation into the non-replicating adenoviral vector. The 600 bp of EGR-1 promoter were cloned upstream of the luciferase gene sequence as reporters.

whose light emission can be quantified in a luminometer. The light counts are dependent on the concentration of the protein in a total cellular extract of exposed cells. In turn, the increase or decrease in luciferase concentration results from negative or positive regulation of the promoter in the presence of different drugs (Fig. 1).

\section{Large-scale production of the Ad-Egr1/Luc7 recombinant adenovirus and AdCMV-hGFP}

Inocula of each virus were packaged in HEK293 cells (Invitrogen Corporation-AATC, USA) and purified on a large scale for in vivo applications from 250 million HEK-293 cells, in D-MEM/F12 medium (50:50) with $5 \mathrm{mM} \mathrm{L-glutamine}$ and $10 \%$ heat-inactivated and filtration-sterilized BFS (Thermo-Hyclone Corp., USA). At the end of the infection time, the packaging cells were maintained under usual culture conditions for virion maturation and were monitored by optical microscopy until the appearance of $90 \%$ of cytopathic effect, which occurred 48 hours after infection (Fig. 2).

Subsequently, the cells were collected, concentrated and lysed by three cycles of thermal shock in liquid nitrogen alternating with a temperature of $37^{\circ} \mathrm{C}$ for 3 minutes, respectively, in a class II-AB laminar flow hood, for purification of the recombinant virions.

\section{Non-replicating adenoviral vectors purification}

In order to separate mature from immature virions, as well as from cellular debris, total lysates were kept cold and purified by ultracentrifugation in cesium chloride gradients at $28,000 \mathrm{G}$, at $4{ }^{\circ} \mathrm{C}$ for 12 hours (WX100 Thermo Corp., USA). Subsequently, the virions were isolated by sterile puncture and dialyzed (in the presence of magnesium and $5 \mathrm{mM} \mathrm{HEPES}$ at $4{ }^{\circ} \mathrm{C}$ for $12 \mathrm{~h}$ ) in a 10K-MWCO membrane cassette (Pierce Bioscience, USA). The purified recombinant virions were diluted in viral preservation solution ( $1 \%$ albumin and $5 \mathrm{mM} \mathrm{HEPES}$ and $\mathrm{Mg}^{++}$) and stored at $-70^{\circ} \mathrm{C}$. The infectivity efficiency and titration of the infecting viral particles were determined with a plate assay in HEK293 cell monolayers in serial dilutions $\left(10^{-6}, 10^{-7}, 10^{-8}\right.$, $\left.10^{-9}, 10^{-10}, 10^{-11}\right)$, as well as by reading the dialysate optical density at $260 \mathrm{~nm}$.

\section{Infection and determination of multiplicity of infection with Ad-CMV-hGFP adenovirus in primary human fibroblasts}

To determine the optimal quantity of recombinant adenovirus necessary for PHF efficient transduction, an AdCMV-hGFP adenovirus that expresses the humanized green fluorescent protein (GFP) was used. For this, $3 \times 10^{5}$ cells were seeded in six-well boxes (Costar, Madison, USA). After 24 hours, the cells were infected at $25,50,75,100$ and 200 multiplicity of infection (MOI) ratios with the $A d-C M V$ - $h$ GFP reporter adenovirus in serum-reduced medium. After 2-hour exposure, the infectious medium was replaced with fresh medium and the transduced cells were maintained on culture for 24 hours. To document infection efficiency, the GFP signal was sought using an Axioplan 2 equipment (Carl Zeiss, Germany). GFP emitted an excitable light signal at $488 \mathrm{~nm}$ in $A d-C M V$-hGFP adenovirus-infected cells.

\section{Identification of the EGR-1 protein in human fibroblasts}

The co-localization of the EGR-1 protein was carried out by means of immunofluorescence and was 


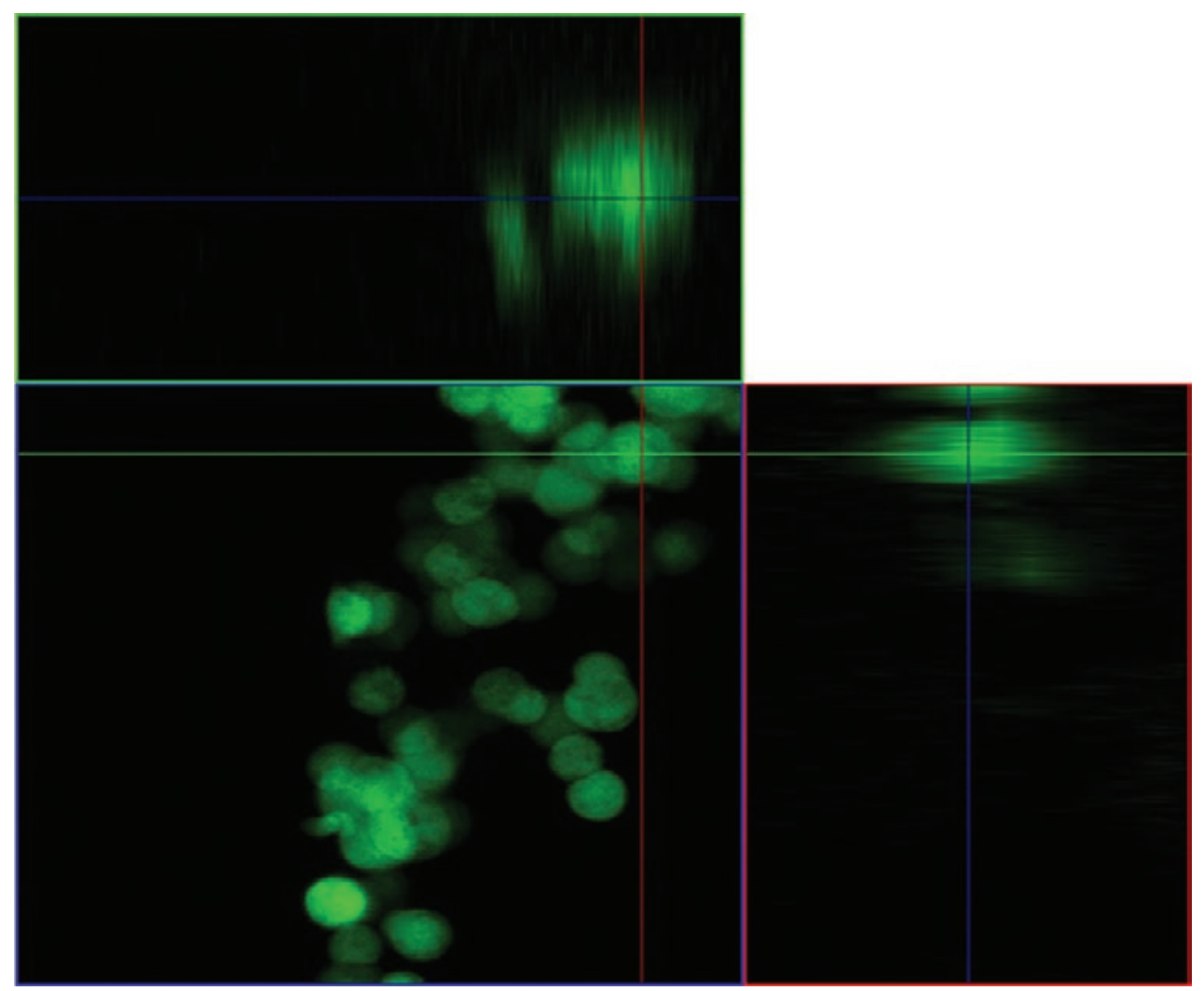

Figure 2. Ad CMV-hGFP virions maturation. The HEK-293 cells were transfected and subsequently infected for large-scale production in order to determine the maturation process of the different virions generated at 48 hours and documented by confocal laser microscopy at $488 \mathrm{~nm}$.

documented by confocal laser microscopy. For this assay, $1 \times 10^{7}$ PHFs were seeded in a culture chamber for microscopy purposes (Slide-chamber Nunc Corp., USA) in D-MEM medium with $2 \%$ FBS. The cells were exposed to UV light for 30 seconds, fixed in PBS and $1 \%$ glutaraldehyde for 10 minutes at $4{ }^{\circ} \mathrm{C}$. The slides were permeabilized with phosphate buffered saline with $1 \%$ Tween 20 (TBS) for 15 minutes, followed by 4 hours of blockage at $4{ }^{\circ} \mathrm{C}$ with $100 \mathrm{mM}$ glycine in TBS. Incubation with the primary antibody was performed in $0.5 \%$ TBS and $1 \%$ albumin with a 1:100 dilution of the human anti-EGR-1 IgG antibody developed in rabbits (Santacruz, Biotech). A secondary anti-rabbit antibody developed in mice and coupled to PE-Cy7 was used at the dilution recommended by the manufacturer and incubated for 2 hours at $4{ }^{\circ} \mathrm{C}$. The slides were washed and covered with Vecta Shield mounting medium (Santacruz, Biotech) for analysis at $630 \mathrm{~nm}$ by confocal laser microscopy on a LSM-100 Meta equipment (Carl Zeiss, Germany).

\section{Drug-induced luciferase reporter assay}

$3 \times 10^{5}$ PHF were seeded in a six-well box under standard culture conditions until their adherence. After
12 hours, the medium was replaced with $1 \%$ FBS to reduce endogenous EGR-1 promoter activity to baseline values during the following 24 hours. At the end of this period, the medium was replaced by D-MEM medium (Gibco-Invitrogen Corp., USA) with drugs at the following concentrations: testosterone $25 \mathrm{ng} / \mathrm{ml}$, beta-estradiol $50 \mathrm{ng} / \mathrm{ml}$, hydrocortisone $50 \mathrm{ng} / \mathrm{ml}$, betamethasone $50 \mathrm{ng} / \mathrm{ml}$ and by EGF-1 at a concentration of $50 \mathrm{ng} / \mathrm{ml}$, all for 1,3 and 6 hours. At the end of each period, the cells were lysed for protein extraction and luminometry analysis.

\section{Total protein extraction}

Total protein extraction from cells exposed to different drugs was carried out as follows: at the end of the exposure time (1, 3 and $6 \mathrm{~h}$ ) the cells were washed with PBS (with $\mathrm{Ca}^{++}$and $\mathrm{Mg}^{+}$) (Invitrogen Corp.) at 37 ${ }^{\circ} \mathrm{C}$ and lysed with $300 \mu$ of lysis solution (Glo-Cell lysis Buffer, Promega Corp., USA) at room temperature for 5 minutes. The lysate was collected in a sterile microtube, stirred for 1 minute and immediately centrifuged at $5000 \mathrm{G}$ at $4{ }^{\circ} \mathrm{C}$. The supernatant was recovered and stored at $-20^{\circ} \mathrm{C}$ until its reading in a luminometry quantifier. 


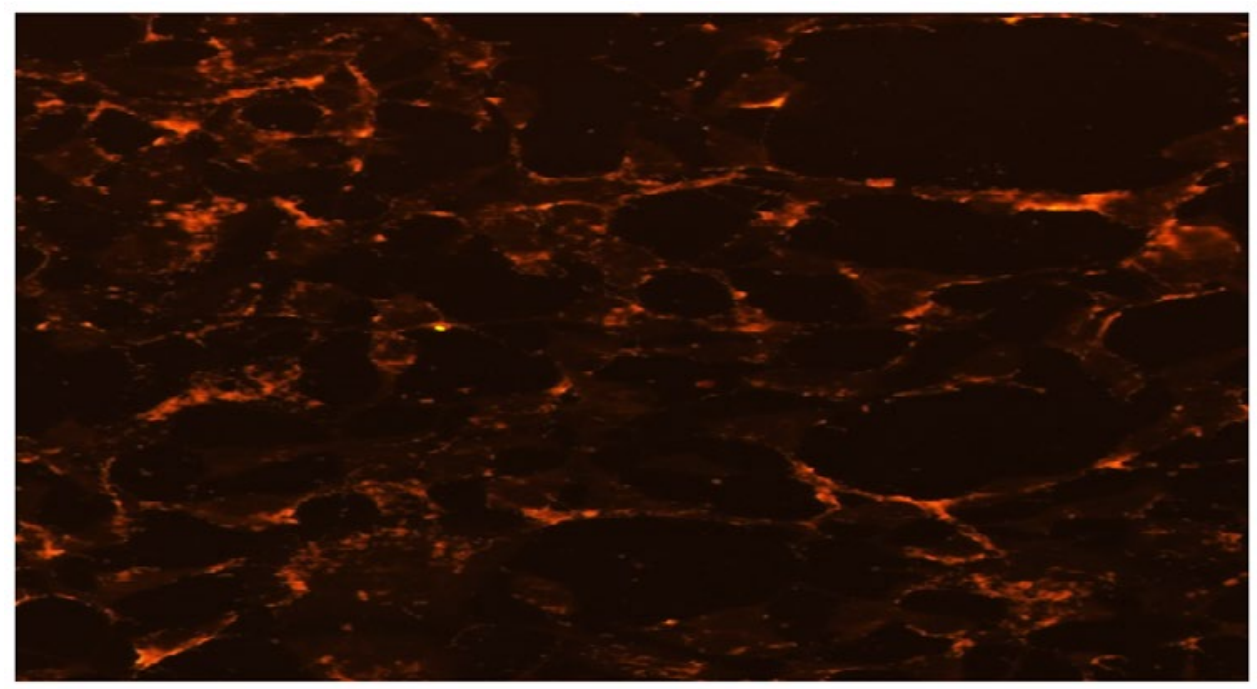

Figure 3. EGR-1 protein co-localization. Human anri-EGR-1 antibody-coupled rhodamine showed ultraviolet light-exposed fibroblasts cytoplasmic and nuclear localization.

\section{Luciferase activity quantification}

Luminometry assays were carried out with $50 \mu$ l of the cell lysate, at a 1:1 ratio of Glo-Luciferase substrate volumes (Promega, USA). The mixture was incubated for 10 minutes at $23^{\circ} \mathrm{C}$ and the reaction was immediately quantified in a luminometer (DTX-800 Beckman Coulter). The luciferase present in the protein extract hydrolyzes the luciferin in the presence of ATP, which generates a luminous signal that is identified by the reader and expressed in light counts per second (LC/s). LC/s were adjusted to the protein concentration in order to obtain Egr-1 promoter-controlled luciferase activity actual data. The LC/s analysis was performed with the Multimode Analysis Software program (Beckman Coulter, USA).

\section{Results}

The $\mathrm{MOI}$ required to efficiently transduce PHFs was determined with the $A d-C M V$ - $h G F P$ reporter adenovirus. The data obtained indicated that the use of a $\mathrm{MOI}$ of 75 is sufficient to efficiently transduce the cassette of interest to the PHFs in an episomal form, without producing a cytopathic effect (data not shown).

Previously, typing of the cells obtained and cultured in vitro was carried out with immunolocalization of marker proteins such as actin 1 and collagen I as surface markers (data not shown). This process is systematically carried out to characterize the cells obtained from skin allograft donors.

To determine EGR-1 protein endogenous expression, induction assays were performed in order to overexpress the protein. These assays were carried out by exposing the PHF cells to UV light for $30 \mathrm{sec}-$ onds and processing them for immunolocalization, with cytoplasmic and nuclear localization of the EGR1 protein being shown (Fig. 3).

\section{Effect of steroid drugs on the Egr-1 promoter in primary human fibroblasts}

PHFs transduced with $A d-E g r-1 L u c 7+$ showed a baseline luciferase activity with 1478.33, 1340.66 and $1333.36 \mathrm{LC} / \mathrm{s}$ at 1,3 and 6 hours, respectively. As expected, luminous activity was not found in non-transduced cells, since luciferase is not expressed in human cells (Fig. 4).

The effects of betamethasone, hydrocortisone, testosterone and beta-estradiol were low in comparison with control cells (PHF with 2\% FBS), which showed an activity of $175 \mathrm{LC} / \mathrm{s}$ per microgram of total protein.

Hydrocortisone had a negative effect on the promoter activity. The luminous counts obtained were 781.66 , 1433.66 and $1782.66 \mathrm{LC} / \mathrm{s}$ at 1,3 and 6 hours, respectively. Betamethasone showed an activity of 1254.33 , 1572 and $4419.33 \mathrm{LC} / \mathrm{s}$ at 1,3 and 6 hours, respectively; and beta-estradiol, 2189.66, 2434.66 and $3925.33 \mathrm{LC} / \mathrm{s}$ at the same time-points.

\section{Steroid hormones effect on the primary human fibroblasts promoter}

PHFs were exposed to testosterone and beta-estradiol in order to explore the effect of steroid hormones 


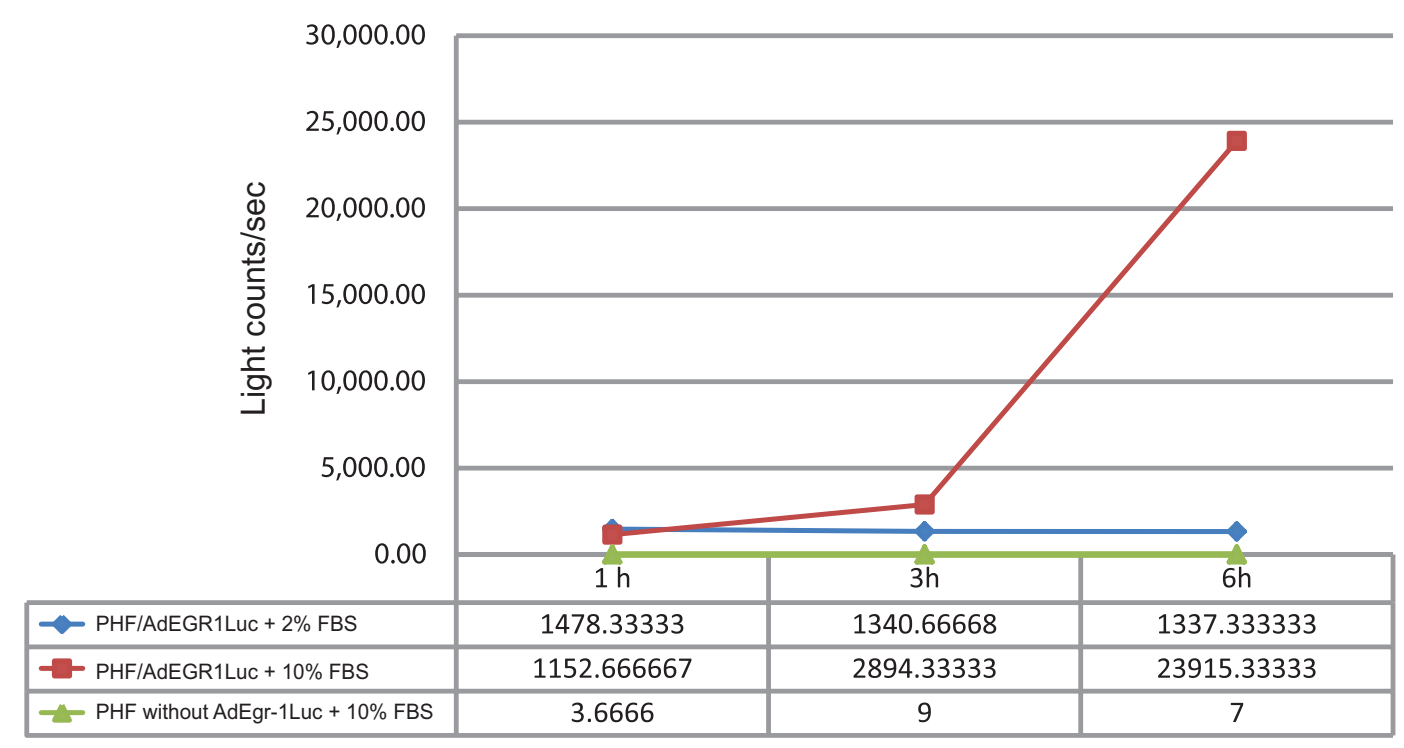

Figure 4. Endogenous promoter baseline activity in primary human fibroblasts (PHF). To determine the effect of inductors on protein expression, the presence of the EGR-1 protein in PHFs was documented, and its expression as a platform for the reporter system action was determined. FBS: fetal bovine serum.

on the EGR-1 promoter in transduced fibroblasts. Testosterone showed 1353, 2720.66 and $2070.33 \mathrm{LC} / \mathrm{s}$ values at 1,3 and 6 hours, respectively. Beta-estradiol showed 2189.662, 1434.66 and $3925.33 \mathrm{LC} / \mathrm{s}$ values at 1,3 and 6 hours, respectively.

\section{Effect of EGF-1 on the promoter in primary human fibroblasts}

A positive regulatory effect was observed in cells exposed to EGF-1. The cell extracts showed an average of 29,511.33 LC/s at 6 hours, with similar values to the positive control (PHFs transduced with AdEgr-1/Luc7+ and exposed to $10 \%$ FBS showed a reading of $23,915.33 \mathrm{LC} / \mathrm{s})$.

\section{Discussion and conclusions}

Cell replication is an indispensable and essential element in tissue repair processes. In the case of patients with large tissue losses, such as heavily burned subjects, cell proliferation is essential for the granulation and healing of injured tissues. The EGR-1 protein is essential for inducing the expression of growth and differentiation factors, as well as activation of mitogenic pathways that promote tissue recruitment, differentiation and repair. However, the initial triggering of this expression mechanism is abolished in the autocrine and paracrine regulatory pathways between keratinocytes, fibroblasts and hair follicle cells, which are absent in heavily burned individuals. The use of drugs that allow maintaining this mechanism stimulated, or identifying negative regulatory effects, is essential to determine the most efficient pharmacological therapeutics for the patient in acute state.

The results obtained suggest that the use of steroids such as betamethasone and hydrocortisone has an inhibitory effect on gene regulation through the EGR-1 promoter, indicating that hydrocortisone has the most potent inhibitory effect of all tested drugs. These effects cannot be concluded as being direct, but they allow determining the promoter biological effect. Testosterone and beta-estradiol also showed an inhibitory growth pattern, with similar values to those of cells in basal conditions (PHF in Ad-egr-1+ with $2 \%$ FBS) (Fig. 5).

\section{EGF-1 positively regulates the EGR-1 promoter}

Interestingly, EGF-1 positively regulates the promoter activity. The increase in luciferase activity shows a similar pattern in relation to the positive control of cells cultured under normal conditions (Fig. 5). This finding allows continuing with further studies to locally use recombinant EGF-1 in heavily burned patients and accelerate the process of clinical recovery, while controlling for negative regulators that withhold this effect after completing the process of tissue repair (Fig. 6). 


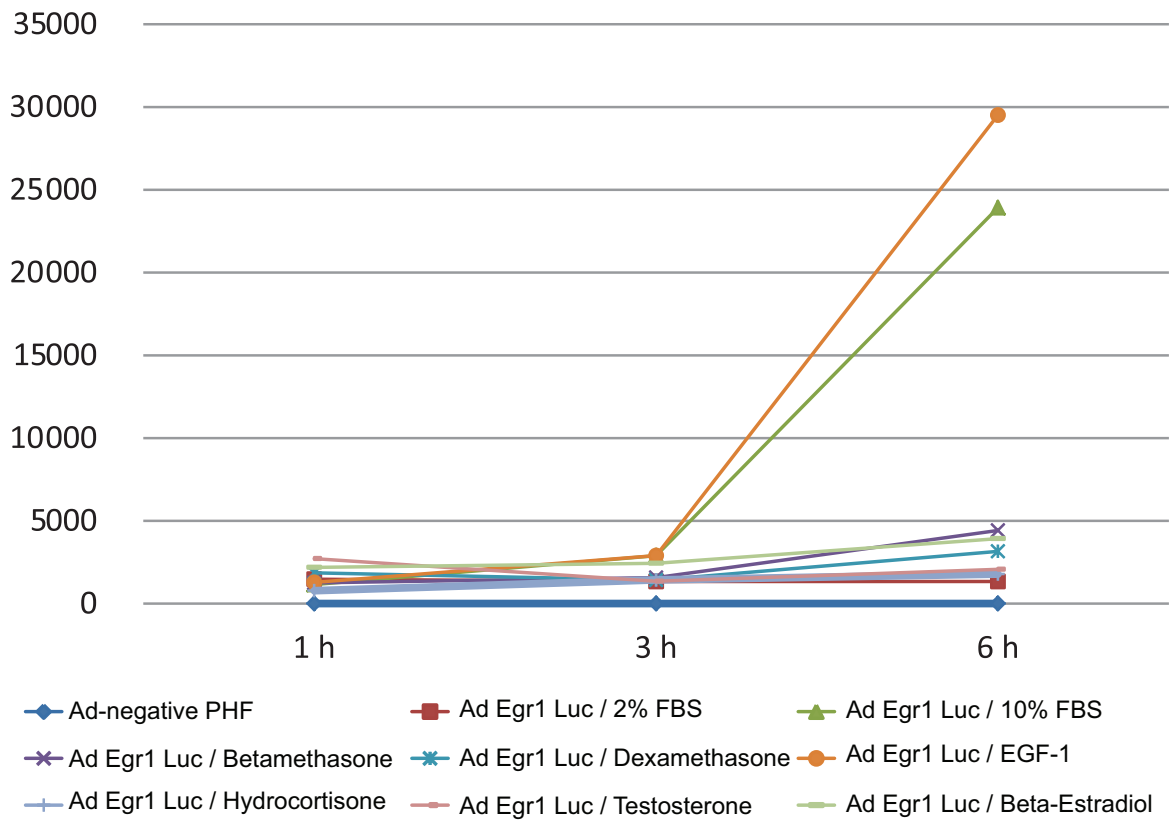

Figure 5. Comparative effect of steroid drugs on the EGR-1 promoter in human fibroblasts. The quantitative analysis of protein extracts of transduced cells exposed to the different drugs is summarized in this graph. The presence of fetal bovine serum (FBS, 10\%) as EGFR-1 activator was used as promoter induction positive control. The graph shows a higher epithelial growth factor-1 stimulation pattern than that of FBS. The other steroidal drugs tested showed lower or similar activity to the baseline expression activity in cells subjected to FBS depletion (2\%).

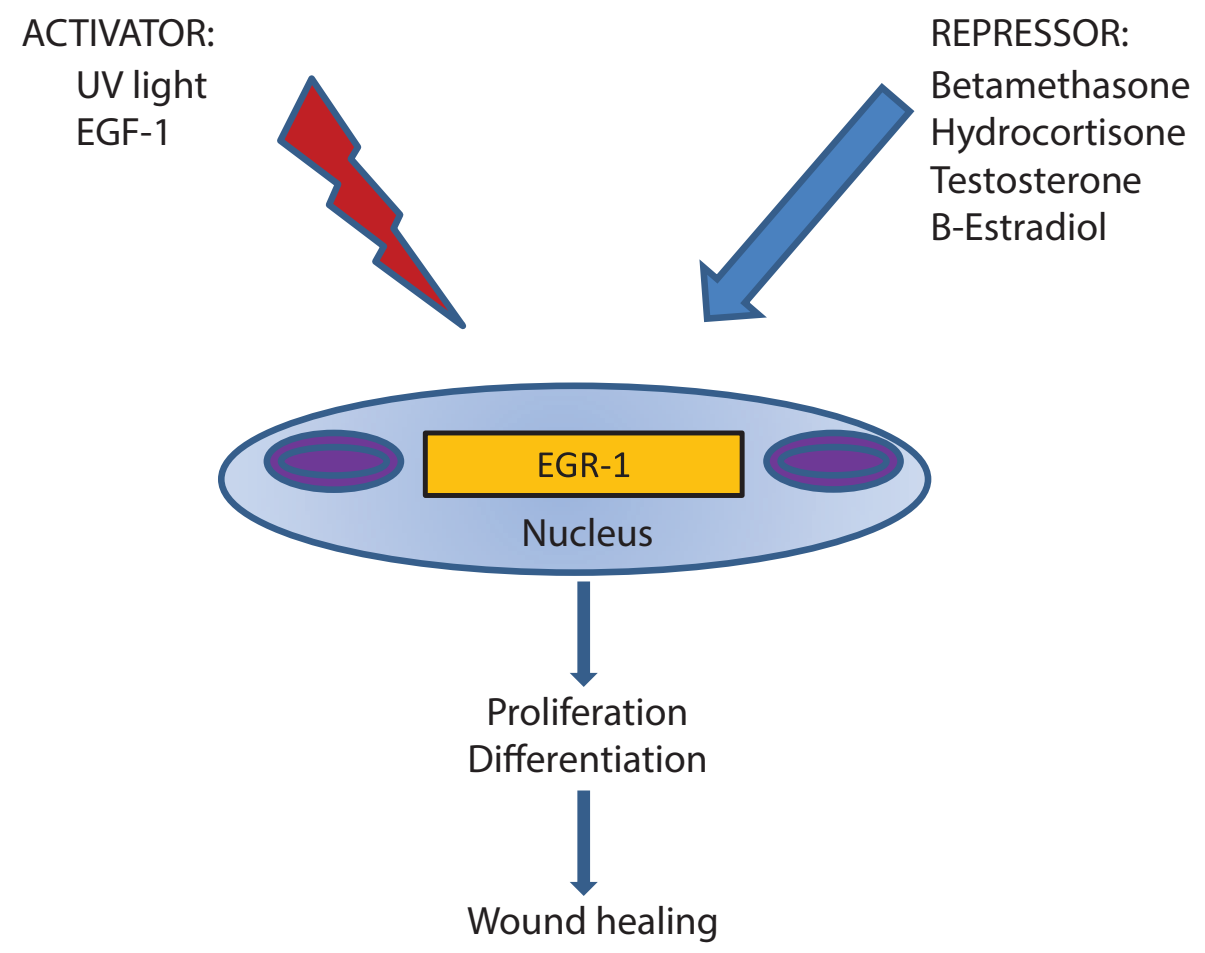

Figure 6. EGR-1 promoter pharmacological regulation model. Ad-Egr-1 Luc adenovirus-infected cells are exposed to ultraviolet light and then are subjected to a medium with $50 \mathrm{ng}$ of betamethasone. The cells are lysed to determine reporter gene activation by light activity quantification.

Even when these drugs have the advantage of being approved for clinical use, further studies are needed to explore their effect on cell proliferation, as well as a study of the mitogenic pathways involved, in order to explore their interaction and clinical utility.

\section{Acknowledgements}

This research was supported by Consejo Nacional de Ciencia y Tecnología (CONACyT) of Mexico through the Fossis-2011-161624 project. 
To Prof. Dr. Bert Vogelstein, from Johns Hopkins University, Baltimore, USA, for kindly donating the AdEasy1 vector system used to generate adenoviral vectors.

To Dr. Kathleen Sakamoto, from Stanford University School of Medicine, USA, for providing the EGR-1 promoter fragment.

In memoriam of Prof. Academician Dr. Hilda Villegas Castrejón, founder of the Molecular Biotherapeutics Program at Instituto Nacional de Rehabilitación Luis Guillermo Ibarra Ibarra, and member of the Mexican Academy of Surgery, AC.

This work was presented within the Mexican Academy of Surgery academic activities and was distinguished with the Academician Dr. Gonzalo Castañeda award on the $83^{\text {rd }}$ academic year.

\section{Ethical responsibilities}

Protection of people and animals. The authors declare that no experiments have been conducted on humans or animals for this research.

Confidentiality of data. The authors declare having followed the protocols of their work center on the publication of patient data.

Right to privacy and informed consent. The authors declare that no patient data appear in this article.

\section{Conflicts of interest}

The authors declare there are no conflicts of interest.

\section{References}

1. Sukhatme VP. Early transcriptional events in cell growth: the Egr family. J Am Soc Nephrol. 1990;1:859-66.

2. Zwang $Y$, Sas-Chen A, Drier $Y$, Shay T, Avraham R, Lauriola M, et al. Two phases of mitogenic signaling unveil roles for p53 and EGR1 in elimination of inconsistent growth signals. Mol Cell. 2011;42:524-35.

3. Sakamoto KM, Fraser JK, Lee HJ, Lehman E, Gasson JC. Granulocyte macrophage colony-stimulating factor and interleukin-3 signaling pathways converge on the CREB-binding site in the human egr-1 promoter. Mol Cell Biol. 1994;14:5975-85.
4. Sakamoto KM, Bardeleben C, Yates KE, Raines MA, Golde DW, Gasson JC. 5' upstream sequence and genomic structure of the human primary response gene, EGR-1/TIS8. Oncogene. 1991;6:867-71.

5. Aicher WK, Sakamoto KM, Hack A, Eibel H. Analysis of functional elements in the human Egr-1 gene promoter. Rheumatol Int. 1999;18:207-14.

6. Schwachtgen JL, Campbell CJ, Braddock M. Full promoter sequence of human early growth response factor-1 (Egr-1): demonstration of a fifth functional serum response element. DNA Seq. 2000;10:429-32.

7. Rolli M, Kotlyarov A, Sakamoto KM, Gaestel M, Neininger A. Stress-induced stimulation of early growth response gene-1 by p38/stress-activated protein kinase 2 is mediated by a cAMP-responsive promoter element in a MAPKAP kinase 2-independent manner. J Biol Chem. 1999;274: 19559-64.

8. Mora-Garcia P, Sakamoto KM. Granulocyte colony-stimulating factor induces Egr-1 up-regulation through interaction of serum response element-binding proteins. J Biol Chem. 2000;275:22418-26.

9. Huang RP, Fan Y, Boynton AL. UV irradiation upregulates Egr-1 expression at transcription level. J Cell Biochem. 1999;73:227-36

10. Martínez-Flores F, Machuca-Rodríguez C, Sandoval-Zamora $\mathrm{H}$, Aguirre-Cruz L, Valdez-Flores M, Villegas-Castrejón H. Steroid drugs and GM-CSF modulates activity of EGR-1 in glioma cells. Cir Cir. 2013;81:3-13.

11. Pritchard MT, Malinak RN, Nagy LE. Early growth response (EGR)-1 is required for timely cell-cycle entry and progression in hepatocytes after acute carbon tetrachloride exposure in mice. Am J Physiol Gastrointest Liver Physiol. 2011;300:G1124-31.

12. He TC, Zhou S, da Costa LT, Yu J, Kinzler KW, Vogelstein B. A simplified system for generating recombinant adenoviruses. Proc Natl Acad Sci USA. 1998;95:2509-14

13. Martínez-Flores F, Jiménez-Orozco FA, Villegas-Castrejón H. Molecular biology of adenoviral vectors. Cir Cir. 2006;74:483-93.

14. Hsu H, Rainov NG, Quinones A, Eling DJ, Sakamoto KM, Spear MA. Combined radiation and cytochrome CYP4B1/4-ipomeanol gene therapy using the EGR1 promoter. Anticancer Res. 2003:23:2723-8.

15. Ernst A, Aigner M, Nakata S, Engel F, Schlotter M, Kloor M, et al. A gene signature distinguishing CD133hi from CD133-colorectal cancer cells: essential role for EGR1 and downstream factors. Pathology. 2011:43:220-7.

16. Neuhaus T, Stier S, Totzke G, Gruenewald E, Fronhoffs S, Sachinidis A, et al. Stromal cell-derived factor 1alpha (SDF-1alpha) induces gene-expression of early growth response-1 (Egr-1) and VEGF in human arterial endothelial cells and enhances VEGF induced cell proliferation. Cell Prolif. 2003;36:75-86.

17. Perogamvros I, Ray DW, Trainer PJ. Regulation of cortisol bioavailability effects on hormone measurement and action. Nat Rev Endocrinol 2012;8:717-27.

18. Stahn C, Löwenberg M, Hommes DW, Buttgereit F. Molecular mechanisms of glucocorticoid action and selective glucocorticoid receptor agonists. Mol Cell Endocrinol. 2007;275:71-8.

19. Pezzoli D, Chiesa R, De Nardo L, Candiani G. We still have a long way to go to effectively deliver genes! J Appl Biomater Function Mater. 2012;27;10:e82-91.

20. Runge-Morris M, Rose K, Kokarec TA. Regulation of rat hepatic sulfotransferase gene expression by glucocorticoid hormones. Drug Metab Dispos. 1996;24:1095-101.

21. Shin SY, Kim JH, Baker A, Lim Y, Lee YH. Transcription factor Egr-1 is essential for maximal matrix metalloproteinase- 9 transcription by tumor necrosis factor alpha. Mol Cancer Res. 2010;8:507-19.

22. Tiganescu A, Tahrani AA, Morgan SA, Otranto $M$, Desmoulière $A$ Abrahams $L$, et al. 11 $\beta$-Hydroxysteroid dehydrogenase blockade prevents age-induced skin structure and function defects. J Clin Invest. 2013;123:3051-3060.

23. Werth BB, Bashir M, Chang L, Werth VP. Ultraviolet irradiation induces the accumulation of chondroitin sulfate, but not other glycosaminoglycans, in human skin. PLoS One. 2011;6:e14830. 